\title{
FUKUCHILITE, $\mathrm{Cu}_{3} \mathrm{FeS}_{8}$, A NEW MINERAL FROM THE HANAWA MINE, AKITA PREFECTURE, JAPAN
}

\author{
YoshIMICHI KAJIWARA* \\ Geological Institute, Faculty of Science, University \\ of Tokyo, Hongo, Tokyo
}

\begin{abstract}
A new Cu-Fe-S mineral found from the Hanawa mine, one of the Kurokotype deposits in Japan, is described. The mineral occurs in a certain baritebearing zone of the gypsum (and/or anhydrite) ore body in the mine, closely associated with pyrite and covellite.

Ore-microscopic properties of the mineral are as follows: Reflection colour is very similar to that of bornite, bright pinkish brown in air and purplish brown in oil. Reflectivity is slightly lower than that of pyrite and distinctly higher than that of bornite. Polishing hardness is slightly lower than pyrite and nearly equal to cholcopyrite. Neither internal reflection nor reflection pleochroism is observed, and the mineral is isotropic.

The results of X-ray fluorescent, spectroscopic, chemical, and electron probe analyses revealed that the chemical formula of this mineral is close to $\mathrm{Cu}_{3} \mathrm{FeS}_{8}$. The X-ray powder data was found to be indexed by a cubic cell with $a_{0}=5.58 \AA$. The results of some thermal experiments indicated that this mineral is decomposed to pyrite plus covellite at a certain temperature close to $200^{\circ} \mathrm{C}$ in the presence of sulphur-rich liquid and vapour.

The author proposes the name 'fukuchilite' for this new mineral, in honor of the late Mr. Nobuyo Fukuchi (1877-1934), famous Japanese mineralogist and geologist, who studied many Kuroko-type ore deposits in Japan. This mineral will give us significant information on the genesis of the Kurokotype ore deposits as well as on low-temperature phase relations in the system $\mathrm{Cu} \cdot \mathrm{Fe}-\mathrm{S}$.
\end{abstract}

* Present address: Geological and Mineralogical Institute, Faculty of Science, Tokyo University of Education. 


\section{Introduction}

In April, 1964, an unknown mineral with light pinkish brown colour was found in barite-bearing gypsum (and/or anhydrite) ores from the Hanawa mine. Chemical, thermal, and $X$-ray studies on the mineral revealed that it is a new mineral in the system $\mathrm{Cu}-\mathrm{Fe}$ $\mathrm{S}$ with the formula close to $\mathrm{Cu}_{3} \mathrm{FeS}_{8}$. The author proposes the name 'fukuchilite' for this new mineral, in honor of the late Mr. Nobuyo Fukuchi (1877-1934), famous Japanese mineralogist and geologist, who studied many Kuroko-type ore deposits in Japan. In the present paper the mode of occurrence, chemical composition, X-ray powder data, and thermal behaviours of fukuchilite are described. This mineral species and its name have been approved by the Commission on New Minerals and Mineral Names, the IMA.

\section{Mode of occurrence}

The Hanawa mine which is one of the Kuroko-type mines in Japan is situated at the north-eastern corner $\left(140^{\circ} 45^{\prime} \mathrm{E}, 40^{\circ} 15^{\prime} \mathrm{N}\right)$ of Akita Prefecture, northern part of Honshu Island. Ore deposits of the mine are found in lenses or layers in acidic pyroclastic rocks of middle Miocene age. Fukuchilite was found from the Motoyama ore deposit, one of the major ore deposits in the mine. The deposit is composed of the three geologic units which are characterized by following mineral assemblages respectively: 1) sphalerite-galenabarite, 2) chalcopyrite-pyrite, and 3) gypsum (and/or anhydrite)-pyrite.

Small masses including fukuchilite (less than $1 \mathrm{~cm}$ in diameter) are scattered in a certain barite-bearing zone of the gypsum (and/or anhydrite) ore body. Although fukuchilite is completely preserved in the anhydrite ores, it is partly or completely decomposed to pyrite plus covellite in gypsum ores.

The fukuchilite-bearing masses are dark brownish grey in colour and submetallic in luster with dark bronze streaks. Under the ore 
-microscope, the masses consist of at least three phases : very minute crystals of hypidiomorphic pyrite, covellite in irregular shapes, and fukuchilite with bright pinkish brown reflection colour in the interstices. The masses sometimes make contact with coarse-grained pyrites. Barite is always associated with these masses. Sphalerite, galena, and tetrahedrite are sometimes found with them, though in small quantities. Chalcopyrite and bornite are found exclusively as inclusions in coarse-grained pyrites, and it should be noted that fukuchilite never comes into contact with them.

Ore-microscopic properties of fukuchilite are summarized as follows :

Reflection colour;

Very similar to bornite. Bright pinkish brown in air.

Purplish brown in oil.

Reflectivity ;

Slightly lower than pyrite. Distinctly higher than bornite. Polishing hardness;

Slightly lower than pyrite. Nearly equal to chalcopyrite. No internal reflection, no reflection pleochroism, and no anisotropism under crossed nicols.

The texture of fukuchilite-bearing masses is very characteristic as shown in Figs. 1a-1d. Fukuchilite fills up interstices of minute crystals of hypidiomorphic pyrite which are homogeneously scattered in the masses. Covellite is rather scarce in the masses from the abundant anhydrite ore, and fukuchilite is rather scarce in those from the gypsum ore. Although there is no distinct textural difference in both cases, the mass from the gypsum ores is rather porous. The porous texture seems to be due to decomposition of fukuchilite into pyrite and covellite during oxidation and hydration processes resulting in the conversion of anhydrite to gypsum. Grobular aggregates of pyrite in various dimensions occur frequently in the fukuchilite-bearing masses. Covellite usually surrounds the 

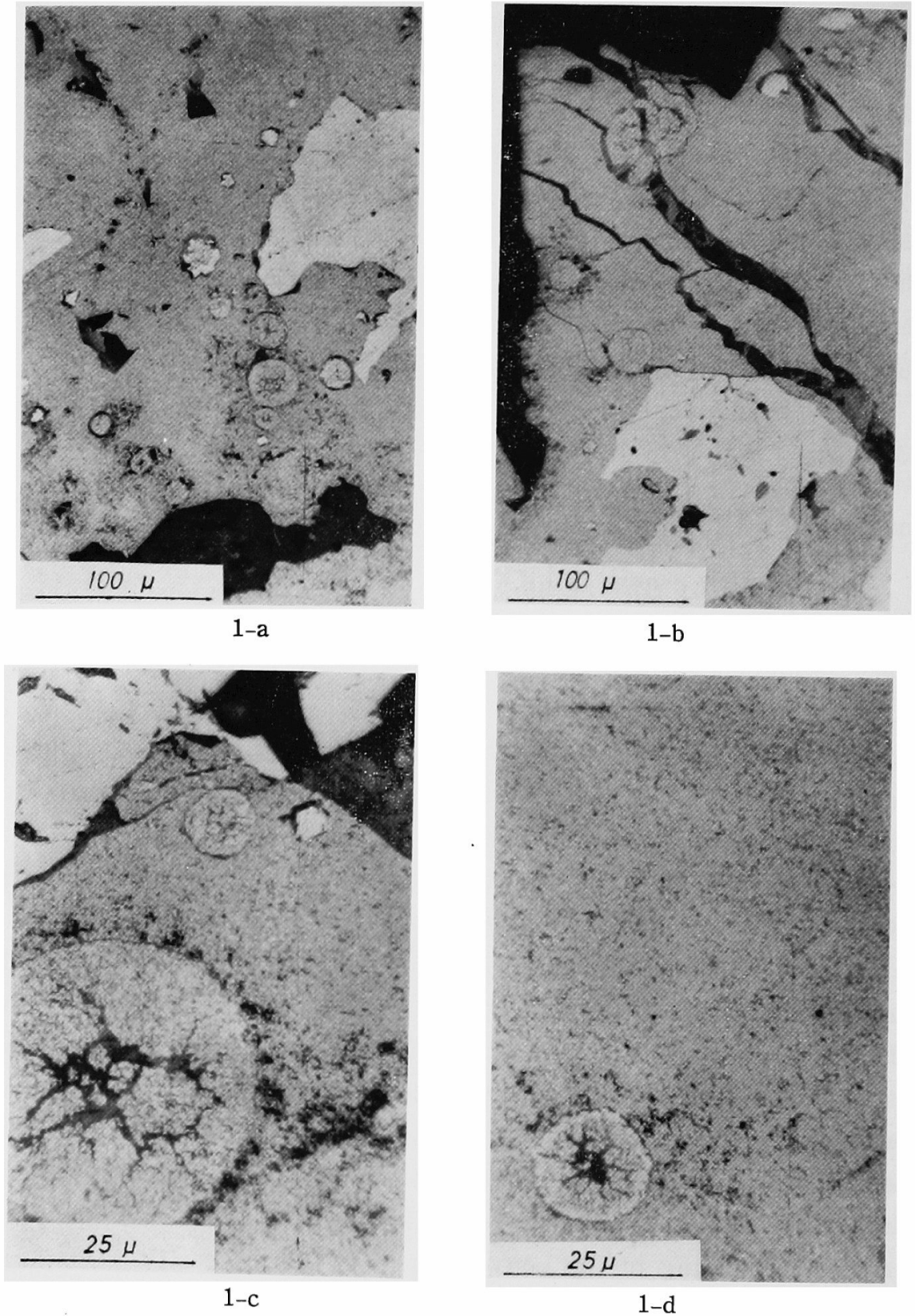

Figs. 1-a, 1-b, 1-c and 1-d. Microphotographs of fukuchilitebearing masses. Pyrite (white), fukuchilite (grey), and covellite (black) are the principal constituents. Areas containing grobular aggregates of pyrite are composed of very minute crystals, covellite in irregular shapes, and fukuchilite cementing the interstices. 
grobular aggregates and also occupies the central portions of them with a starfish-like texture. Fukuchilite is sometimes preserved in the central portions of the grobular aggregates.

\section{Chemical composition}

The results of X-ray fluorescent and spectroscopic analyses of the aggregates composed mainly of pyrite, fukuchilite, and covellite indicate that copper, iron, and sulphur are the principal constituents. Traces of zinc, lead, silver, arsenic, and antimony probably derived from sphalerite, galena, and tetrahedrite existing in small amounts have been detected, but none of the other elements.

Qualitative and quantitative analyses of fukuchilite have been made with the electron probe X-ray microanalyser (Model JXA-3A of Nihon Denshi Co. Ltd.). For qualitative analyses, quartz, mica, $\mathrm{KAP}$, and $\mathrm{Pb}$-st. were used as analysing crystals. The results revealed that fukuchilite is composed essentially of copper, iron, and sulphur as shown in Fig. 2, and that none of the other elements
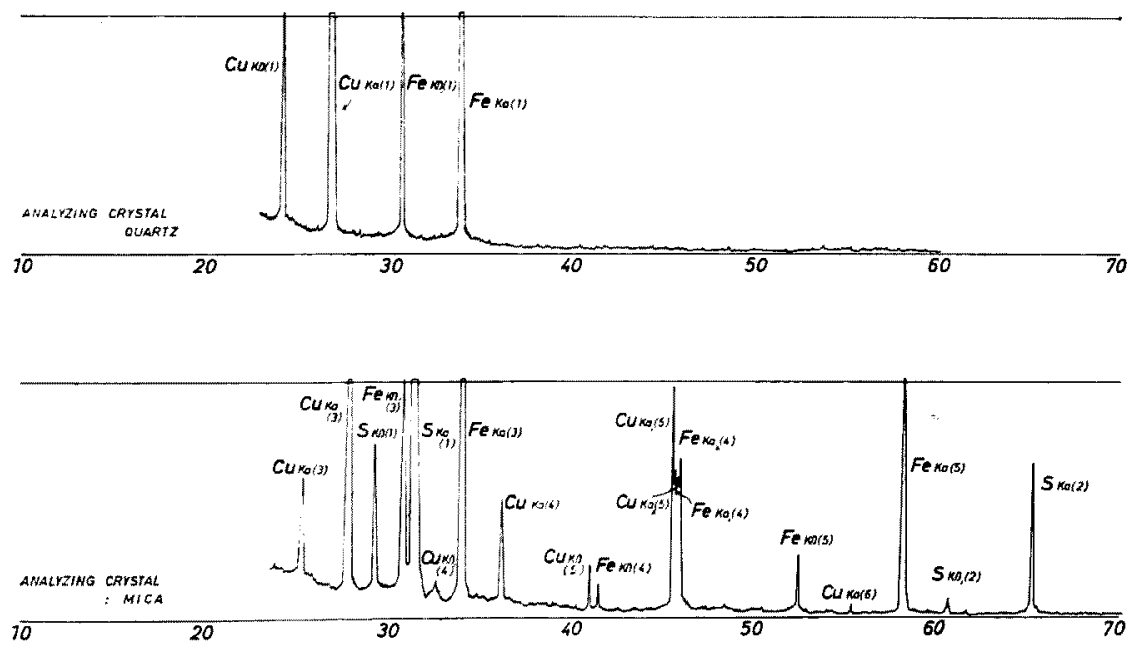

Fig. 2. Qualitative analyses of fukuchilite by electron probe microanalyser (Model JXA-3A of Nihon Denshi Co. Ltd.). 
from boron to uranium is detected. Chemical homogeneity of the mineral is also confirmed by repeated probe analyses.

Using analysed chalcopyrite specimen, and metallic iron and copper as standard materials, the chemical composition of fukuchilite has been quantitatively determined. As shown by the observed intensities of $\mathrm{Cu} K \alpha, \mathrm{Fe} K \alpha$, and $\mathrm{S} K \alpha$ radiations for chalcopyrite,

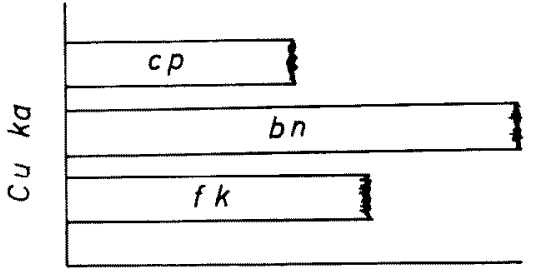

intensity

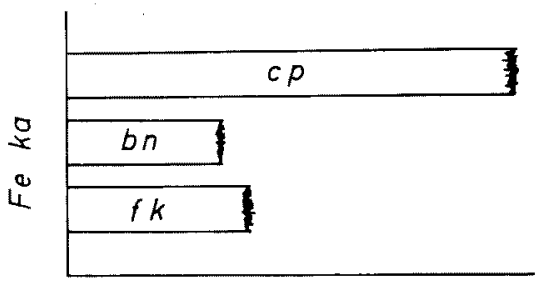

intensity

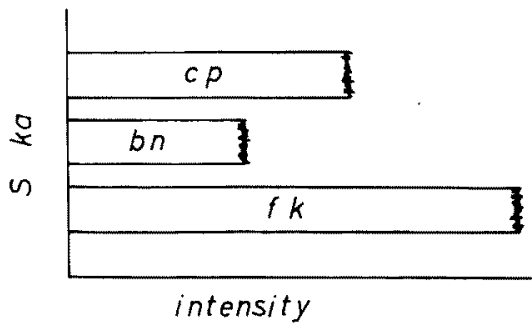

Fig. 3. Observed intensities of $\mathrm{Cu} K \alpha, \mathrm{Fe} K \alpha$ and $\mathrm{S} K \alpha$ radia. tions for chalcopyrite (Ani Mine, $\mathrm{Cu}=34.59 \% \quad \mathrm{Fe}=30.5_{6} \% \quad \mathrm{~S}=34.8_{5}$ $\%$ ), bornite (Sazare mine, $\mathrm{Cu}=$ $63.1_{0} \% \mathrm{Fe}=11.5_{4} \% \quad \mathrm{~S}=25.3_{6} \%$ ), and fukuchilite. bornite, and fukuchilite (Fig. 3), it is evident that fukuchilite is a new sulphur-rich phase in the system Cu-Fe-S. Its sulphur-rich nature is also well presented in the absorption image for $\mathrm{S} K \alpha$ radiation (Fig. 4-f). Table 1 represents the results of microprobe analyses of fukuchilite, corrected after Birks' and Philibert's methods. The $\mathrm{Cu} / \mathrm{Fe}$ atomic ratio is nearly equal to 3.0 , and the $\mathrm{S} /$

Fig. 4-a. Microphotograph showing the area analysed by the electron probe microanalyser. Schematic sketch of the portion represented in absorption images (Figs. $4-c$ to $4-f$ ) is shown in Fig. 4-b. (Figs. 4-a and 4-b mutually bisymmetric.)

Fig. 4-b. Sketch of the analysed area. Abbreviations; $p y=p y r i t e, f k=$ fukuchilite, and $\mathrm{cv}=$ covellite.

Fig. 4-c. Electron absorption image.

Fig. 4-d. Absorption image for Fe $K \alpha$ radiation.

Fig. 4-e. Absorption image for $\mathrm{Cu} K \alpha$ radiation.

Fig. 4-f. Absorption image for $\mathrm{S}$. $K \alpha$ radiation. 

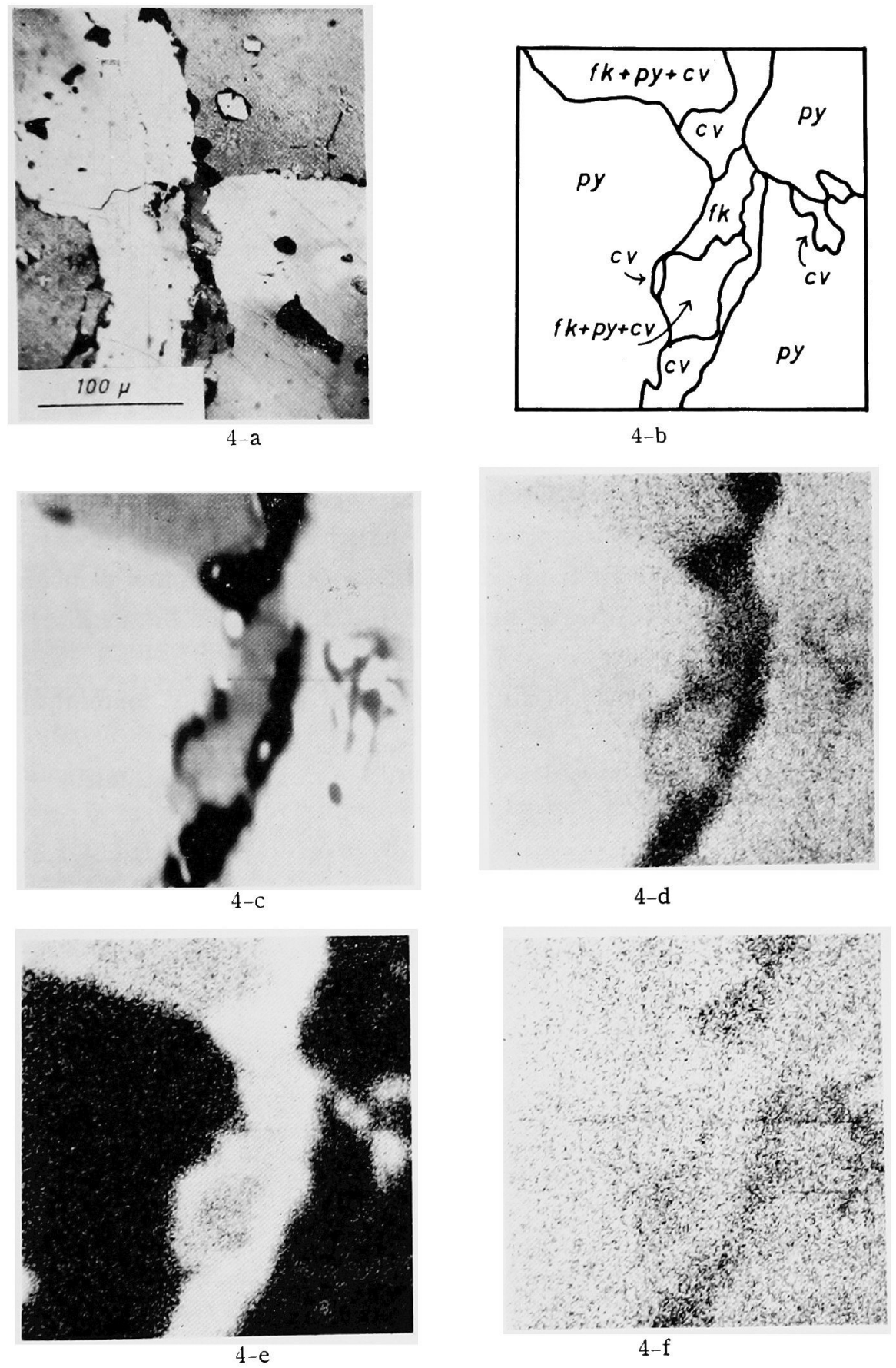
406 Fukuchilite, $\mathrm{Cu}_{3} \mathrm{FeS}_{8}, \mathrm{~A}$ New Mineral from the Hanawa Mine

Table 1. Microprobe analyses of fukuchilite.

1. Determination* of $\mathrm{Cu}$ and $\mathrm{Fe}$ for 5 specimens using $\mathrm{Cu}$ and Fe metals as standards:
$\mathrm{Cu}$ wt. \%
Fe wt. $\%$
38. $4-39.1$
$11.0-11.5$

2. Determination* of $\mathrm{Cu}, \mathrm{Fe}$ and $\mathrm{S}$ for 19 specimens using analysed chalcopyrite as standard:
$\mathrm{Cu}$ wt. $\%$
Fe wt. $\%$
S wt. \%
$37.9-40.6$
10. $5-12.9$
$49.2-53.3$

* Corrected values by Birks' and Philibert's methods.

$\mathrm{Cu}+\mathrm{Fe}$ atomic ratio lies in the range between 1.7 and 2.1. This may suggest that the composition of fukuchilite exhibits a deviation from the stoichiometric metal disulphide form to a sulphur defficient one. In any case, it can be said that the formula of fukuchilite is very close to $\mathrm{Cu}_{3} \mathrm{FeS}_{8}$.

Table 2 shows the results of chemical analyses of mineral ag-

Table 2. Chemical analyses of mixtures containing fukuchilite.

\begin{tabular}{l|r|r|l|r|r}
\hline \multicolumn{3}{c|}{ Sample No. 1 } & \multicolumn{3}{c}{ Sample No. 2} \\
\hline & wt. $\%^{*}$ & atomic $\%^{* *}$ & & wt. \%* & atomic \%** \\
\hline $\mathrm{Cu}$ & 19.52 & 13.64 & $\mathrm{Cu}$ & 20.29 & 13.60 \\
$\mathrm{Fe}$ & 29.16 & 23.18 & $\mathrm{Fe}$ & 30.49 & 23.24 \\
$\mathrm{~S}$ & 45.61 & 63.18 & $\mathrm{~S}$ & 47.49 & 63.16 \\
$\mathrm{BaSO}_{4}$ & 3.73 & & $\mathrm{ZnS}$ & 0.82 & \\
$\mathrm{CaSO}_{4}$ & 0.12 & & BaSO $_{4}$ & 0.19 & \\
$\mathrm{H}_{2} \mathrm{O}^{-}$ & 1.37 & & $\mathrm{CaSO}_{4}$ & trace & \\
\hline Total & 99.51 & $(100.00)$ & Total & 99.28 & $(100.00)$ \\
\hline
\end{tabular}

(Analyst: H. Haramura, 1964)

* Contents of $\mathrm{Ba}, \mathrm{Ca}$, and $\mathrm{Zn}$ are recalculated and represented as their mineral formulas existing in the mixtures analysed.

** $\mathrm{Cu} / \mathrm{Cu}+\mathrm{Fe}+\mathrm{S}, \mathrm{Fe} / \mathrm{Cu}+\mathrm{Fe}+\mathrm{S}$ and $\mathrm{S} / \mathrm{Cu}+\mathrm{Fe}+\mathrm{S}$ are represented. 


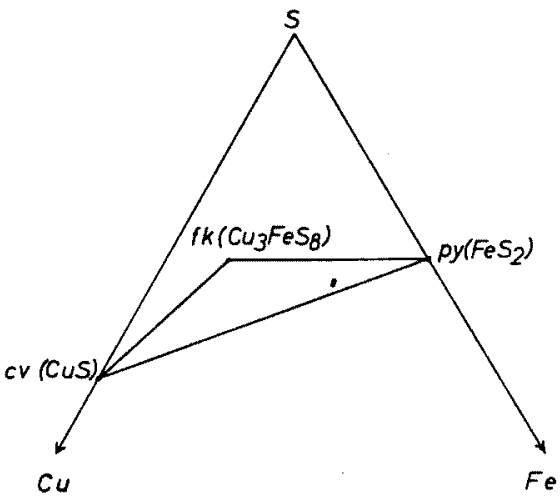

Fig. 5. Bulk compositions for mixtures of pyrite, fukuchilite, and covellite (in atomic \%).

gregates composed mainly of pyrite, fukuchilite, and covellite with minor amounts of sphalerite, barite, and gypsum (and/or anhydrite). Subtracting constituents of minerals which do not belong to the system $\mathrm{Cu}-\mathrm{Fe}-\mathrm{S}$ from the bulk composition of the mixture of pyrite, fukuchilite, and covellite can be plotted onto the $\mathrm{Cu}-\mathrm{Fe}-\mathrm{S}$ ternary diagram. The compositions plotted in this manner lie, as shown in Fig. 5 , in a triangular area bounded by compositional points of pyrite $\left(\mathrm{FeS}_{2}\right)$, covellite (CuS), and fukuchilite $\left(\mathrm{Cu}_{3} \mathrm{FeS}_{8}\right)$. This evidence strongly supports the chemical composition as determined for this mineral by the electron probe studies.

\section{$X$-ray powder data}

Single-crystal study was impossible for the present material because of its extremely fine grain-size. Table 3 represents $X$-ray powder data for the aggregate of pyrite, covellite, and fukuchilite. The data of fukuchilite are similar to those of pyrite, but suggest a lower symmetry. The strong lines are $3.21(\mathrm{~s})(111), 2.789$ (vs) (200), $2.497(\mathrm{w})(210), 2.281(\mathrm{~m})(211), 1.971(\mathrm{w})(220), 1.685(\mathrm{~s})(311)$, and $1.545(\mathrm{w})$ (320), as indexed on a cubic cell with $a_{0}=5.58 \AA$. With $Z=1$, this 
408 Fukuchilite, $\mathrm{Cu}_{3} \mathrm{FeS}_{8}, \mathrm{~A}$ New Mineral from the Hanawa Mine

Table 3. X-ray powder data for the three-phase aggregate of pyrite, fukuchilite, and covellite.

\begin{tabular}{|c|c|c|c|c|c|c|}
\hline $2 \theta$ & $d(\AA)$ & $I$ & $h k l^{*}$ & py & $\mathrm{cv}$ & $\mathrm{fk}$ \\
\hline 22.4 & 3.96 & vvw & 110 & - & - & 0 \\
\hline 27.7 & 3. 21 & s & 111 & - & $(O)$ & 0 \\
\hline 28.58 & 3. 120 & & & 0 & - & - \\
\hline 29.18 & 3. 057 & & & - & 0 & - \\
\hline 31.80 & 2. 811 & & & - & 0 & - \\
\hline 32.05 & 2.789 & vs & 200 & - & - & 0 \\
\hline 32.90 & 2.720 & & & 0 & 0 & - \\
\hline 35.92 & 2. 497 & $\mathrm{w}$ & 210 & - & - & 0 \\
\hline 37.00 & 2. 427 & & & 0 & - & - \\
\hline 39.46 & 2. 281 & $\mathrm{~m}$ & 211 & - & - & 0 \\
\hline 40.70 & 2. 215 & & & 0 & - & - \\
\hline 46.00 & 1. 971 & $w$ & 220 & - & - & 0 \\
\hline 47.34 & 1.918 & & & 0 & - & - \\
\hline 47.90 & 1.897 & & & - & 0 & - \\
\hline 54.40 & 1. 685 & $\mathrm{~s}$ & 311 & - & - & 0 \\
\hline 56.22 & 1. 634 & & & 0 & - & - \\
\hline 59.78 & 1. 545 & $w$ & 320 & - & - & 0 \\
\hline
\end{tabular}

Instrument: Norelco X-ray diffractometer, $40 \mathrm{kV}-15 \mathrm{~mA}$.

Abbreviations: $p y=p y r i t e, c v=$ covellite, and $f k=$ fukuchilite.

* The powder data for fukuchilite are indexed with a cubic cell with $a_{0}=5.58 \AA$.

gives 4.80 as the calculated density G. A pycnometer determination of a mixture containing about $50 \%$ pyrite, $35 \%$ fukuchilite, and $15 \%$ covellite in volume percentage produced $G=4.9_{1}$, which gives $G=4.8_{6}$ for fukuchilite.

Recently, Munson (1966) synthesized $\mathrm{CuS}_{1.9}$, a crystal of pyrite type $\left(a_{0}=5.796 \AA\right)$ at temperatures above $300^{\circ} \mathrm{C}$ and under the pressure of above $20 \mathrm{~kb}$. The unit cell and density of fukuchilite are smaller and larger respectively than those given by the interpolation of a straight line passing the values for pyrite and the synthesized $\mathrm{CuS}_{1.9}$. 


\section{Thermal behaviours}

In order to know the approximate stability field of fukuchilite, some thermal experiments have been performed.

\section{I) Heating experiments in evacuated tubes}

At all temperatures under investigation $\left(200^{\circ}-600^{\circ} \mathrm{C}\right)$, mineral aggregates consisting mainly of pyrite, fukuchilite, and covellite were used as starting materials. Chips of the mineral aggregates were heated in evacuated and sealed silica-glass tubes containing enough sulphur to provide sulphur-rich liquid and vapour. The solid phases produced by heating were identified by means of ore-microscopy and sometimes X-ray diffractometry.

Table 4. Heating experiments in evacuated condition.

\begin{tabular}{|c|c|c|c|c|}
\hline temp. ${ }^{\circ} \mathrm{C}$ & hrs. & & phases & notes \\
\hline 200 & 24 & py & $\mathrm{cv}$ fk & unchanged. \\
\hline 200 & 48 & py & $\mathrm{cv}$ fk & unchanged. \\
\hline 200 & 72 & py & $\mathrm{cv}$ fk & fk : partly decomposed. \\
\hline 250 & 24 & py & $\mathrm{cV} \quad \mathrm{fk}$ & $\begin{array}{l}\text { fk: negligible amount, with } \\
\text { porous texture. }\end{array}$ \\
\hline 250 & 48 & py & $\mathrm{cv}$ & with porous texture, recrystallized. \\
\hline 290 & 24 & py & $\mathrm{cv}$ & with porous texture, recrystallized. \\
\hline 290 & 48 & py & $\mathrm{cv}$ & with porous texture, recrystallized. \\
\hline 320 & 24 & py & $\mathrm{cv}$ & well recrystallized. \\
\hline 380 & 24 & py & $\mathrm{cv}$ & well recrystallized. \\
\hline 420 & 24 & py & $\mathrm{cv}$ & well recrystallized. \\
\hline 460 & 24 & py & id & well recrystallized. \\
\hline 550 & 24 & py & $\mathrm{dg}(\mathrm{bn})$ & well recrystallized. \\
\hline 600 & 24 & py & $c p d g(b n)$ & $\begin{array}{l}\text { well recrystallized, lattice inter- } \\
\text { growth of } c p \text { and } d g(b n) \text {. }\end{array}$ \\
\hline
\end{tabular}

Starting materials: aggregates of pyrite, fukuchilite, and covellite.

Abbreviations : $p y=$ pyrite, $c v=$ covellite, $f k=f u k u c h i l i t e, ~ i d=i d a i t e$, $\mathrm{dg}(\mathrm{bn})=$ digenite-bornite solid solution, and $\mathrm{cp}=\mathrm{chal}$ copyrite solid solution. 
410 Fukuchilite, $\mathrm{Cu}_{3} \mathrm{FeS}_{8}$, A New Mineral from the Hanawa Mine

Table 4 shows the results of the present heating experiments. From this table, it is evident that mineral assemblages produced by heating above $400^{\circ} \mathrm{C}$ coincide closely with those reported in the work by Roseboom and Kullerud (1958) on the solidus relations of the system $\mathrm{Cu}-\mathrm{Fe}-\mathrm{S}$. The fact that all the products produced by heating the mineral aggregates containing a considerable amount of fukuchilite belong to the system $\mathrm{Cu}-\mathrm{Fe}$-S strongly supports the idea that fukuchilite is an essential mineral phase of the system.

It was also one of the purposes of these experiments to estimate the approximate dissociation temperature of fukuchilite in the presence of sulphur-rich liquid and vapour. As shown in Table 4 , the reaction, fukuchilite $\rightleftarrows$ pyrite +covellite+liquid +vapour, seems to be equilibrated at a certain temperature close to $200^{\circ} \mathrm{C}$, though the invariant condition could not be detected strictly. Any mineral which is dissociated at such a low temperature has never been reported in the system $\mathrm{Cu}-\mathrm{Fe}-\mathrm{S}$. And, it seems that the sulphur-rich formula of fukuchilite, $\mathrm{Cu}_{3} \mathrm{FeS}_{8}$, is reasonable for a phase which is stable at lower temperatures.

The aggregates of pyrite and covellite produced by dissociation of fukuchilite always have porous textures. An interpretation of these porous textures may be found in a decrease of solid volume in the reaction, fukuchilite $\rightleftarrows$ pyrite+covellite+vapour. From the assumption for fukuchilite that its formula is $\mathrm{Cu}_{3} \mathrm{FeS}_{8}$ and its structure is a cubic one with $a_{0}=5.58 \AA$ and $Z=1$, the solid volume change in the above reaction can be calculated as follows.

$$
\begin{aligned}
& \mathrm{Cu}_{8} \mathrm{FeS}_{8} \rightarrow 3 \mathrm{CuS}+\mathrm{FeS}_{2}+\text { vapour } \\
& 104.7 \mathrm{cc} \quad 61.0 \mathrm{cc} \quad 23.9 \mathrm{cc}
\end{aligned}
$$

This reaction, thus, causes a decrease of volume of about $10 \%$. If the assumption is valid, the porous texture of pyrite-covellite aggregates formed by dissociation of fukuchilite will well be explained. 
II) Differential thermal analyses

In order to know the thermal behaviours of fukuchilite, several runs of differential thermal analysis of the mixtures of pyrite, fukuchilite, and covellite have also been performed under both atmospheric and evacuated conditons. The mixtures, under 200 mesh in particle size, were used as starting materials. In the case of runs under the atmospheric condition, the mixtures were enclosed in silica-glass holders and heated in the air-tight furnace of a fully automatic differential thermal analyser. In runs under the evacuated condition, the mixtures were sealed in evacuated silica-glass tubes connected with thermo-couples and heated in the furnace for differential thermal analysis.

Figures 6 and 7 illustrate the results of these differential thermal analyses. As shown in Fig. 6, four distinct endothermic peaks and one exothermic peak were detected in the runs under the atmospheric condition. On the other hand, in the runs under the evacuated condition, all the peaks detected were endothermic as shown in Fig. 7. The exothermic peak in Fig. 6 corresponds to the broad endothermic peak in Fig. 7.

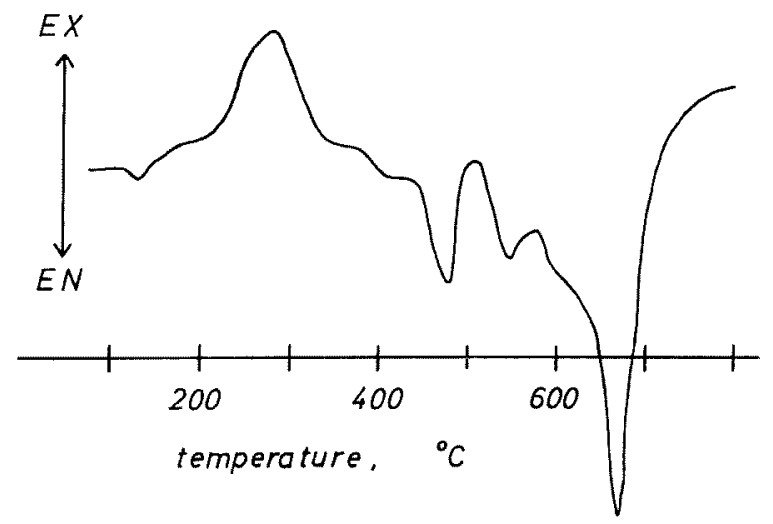

Fig. 6. Differential thermal curve for a mixture of pyrite, fukuchilite, and covellite in atmospheric condition. 
412 Fukuchilite, $\mathrm{Cu}_{3} \mathrm{FeS}_{8}$, A New Mineral from the Hanawa Mine

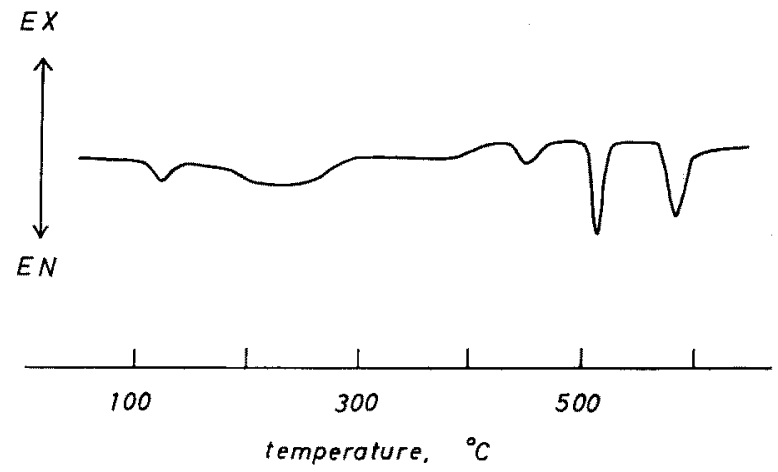

Fig. 7. Differential thermal curve for a mixture of pyrite, fukuchilite, and covellite in evacuated condition.

A small endothermic peak at about $100^{\circ} \mathrm{C}$ observed in both runs is due to dehydration of adsorption water in the samples. On the basis of knowledge on progressive phase-transformations caused by heating the mixtures containing fukuchilite, it is suggested that other peaks detected correspond to the following reactions, fukuchilite $=$ pyrite + covellite + vapour, pyrite + covellite $=$ idaite + vapour, pyrite + idaite $=$ digenite (bornite) + vapour, and pyrite + digenite (bornite) $=$ chalcopyrite + vapour. The exothermic reaction in Fig. 6 is considered to be due to oxidation of sulphur gas produced during the dissociation of fukuchilite by oxygen existing in the air-tight furnace.

The reaction, fukuchilite $=$ pyrite + covellite + vapour, seems to begin at about $200^{\circ} \mathrm{C}$ though the peak representing the reaction is not sharp but broad. A possible interpretation of the broadness of this peak will be given by sluggishness of the dissociation reaction of fukuchilite. Thus, at all events, it can be concluded that the reaction, fukuchilite $=$ pyrite + covellite + liquid + vapour, is equilibrated at a certain temperature close to $200^{\circ} \mathrm{C}$.

\section{Discussions}

Of great significance to discussion on ore genesis is the system $\mathrm{Cu}-\mathrm{Fe}-\mathrm{S}$, which contains most of the sulphides found in a large 
number of ore deposits. Although many workers have investigated various parts of the system ( $c f$. references), the phase relations in the system at lower temperatures have not been well studied yet, mainly because of sluggish reaction rates of the related phases. Under these circumstances, the new sulphur-rich phase described in the present paper will offer significant information about low-temperature phase relations of the system $\mathrm{Cu}-\mathrm{Fe}-\mathrm{S}$.

It is strongly supported by the results of the thermal experiments that the equilibrium temperature of the reaction, fukuchilite $=$ pyrite + covellite, in the presence of sulphur-rich liquid and vapour would be close to $200^{\circ} \mathrm{C}$. Accordingly, the solidus of fukuchilite must lie, as shown in Fig. 8, in the lower temperature region of the diagram given by Roseboom and Kullerud (1958).

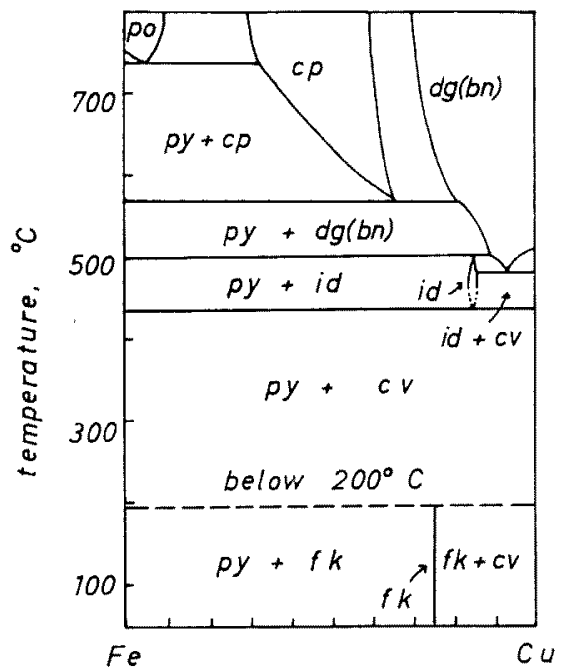

Fig. 8. The solidus of fukuchilite represented in the diagram reported by Roseboom and Kullerud (1958).

Figure 9 represents a tentative stability field of fukuchilite as the function of temperature and partial pressure of sulphur. In the diagram, it is evidently shown that the stability field of fukuchilite 
414 Fukuchilite, $\mathrm{Cu}_{3} \mathrm{FeS}_{8}$, A New Mineral from the Hanawa Mine

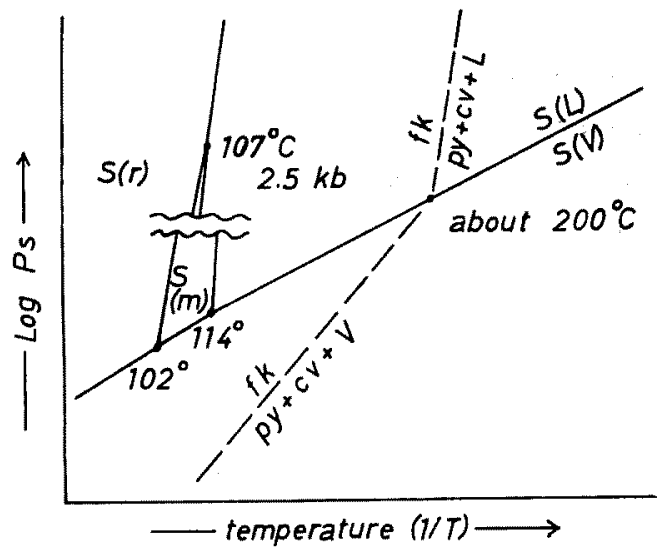

Fig. 9. Tentative diagram showing the stability field of fukuchilite as the function of temperature and partial pressure of sulphur.

extends to that of native sulphur. Therefore, it is the author's opinion that at a condition under which native sulphur is stable, the following mineral assemblages can be stable according to the appropriate $\mathrm{Cu} / \mathrm{Fe}$ ratios; fukuchilite one phase, pyrite-fukuchilite, and fukuchilite-covellite. In other words, pyrite and covellite will not coexist in equilibrium with native sulphur.

The occurrence of fukuchilite indicates an environment intermediate between the hydrothermal metallic vein and the exhalative native sulphur deposit. On the basis of numerous geologic evidences, the Kuroko-type ore deposits are considered to be of hydrothermalsedimentary origin closely related to submarine acidic volcanisms. This environment seems to be in complete harmony with the formation of fukuchilite. And, judging from the thermal stability of fukuchilite, we believe that the fukuchilite-bearing mineral aggregates have been formed below $200^{\circ} \mathrm{C}$.

Since the copper disulphide phase, $\mathrm{CuS}_{1.9}$, was synthesized by Munson (1966), and also a natural occurrence of copper-bearing pyrite was reported from Nukundamu, Fiji, by Frontzel and Ottemann (1967), phase relations along the $\mathrm{CuS}_{2}-\mathrm{FeS}_{2}$ join in which fukuchilite is si- 
tuated should be paid active attention in future.

\section{Acknowledgement}

The author wishes to express his sincere thanks to Prof. T. Watanabe at Nagoya University, Prof. T. Tatsumi at University of Tokyo, and Dr. A. Kato at the National Science Museum of Japan for their kind advice and criticisms. The author is also much indebted to Prof. L. A. Clark at McGill University who has given him useful advice on phase relations of sulphide minerals, and Dr. M. Fleischer at the U. S. Geological Survey who has kindly informed him of the paper by Munson on synthetic copper disulphide. Dr. H. Shima at Yamaguchi University and Mr. H. Nakano at Kanazawa University aided him in differential thermal analyses. Prof. M. Ichikuni at Tokyo Metropolitan University kindly performed the chemical analyses of the chalcopyrite and bornite used as standard materials in the present study.

\section{REFERENCES}

Allen, E. T. \& Lombard, R.H. (1917). Amer. Jour. Sci., 43, 175.

ARNOLD, R.G. (1962). Econ. Geol., 57, 72.

Barton, P.B. \& Toulmin, P. 3rd. (1964). Econ. Geol., 59, 747.

EDWARDS, A. B. (1947). Textures of ore minerals.

Frenzel, G. (1959). Neues Jb. Min. Abh., 93, 87.

Frontzel, G. \& Ottemann, J. (1967). Mineralium Deposita, 1, 307.

Greig, J. W., Jensen, E. \& Merwin, H. E. (1955). C. I. W. Yearbook, 54, 129.

Kullerud, G. (1958). C. I. W. Yearbook, 57, 215.

Kullerud, G. (1960). C. I. W. Yearbook, 59, 114.

Kullerud, G. \& Yoder, H.S. (1959). Econ. Geol., 54, 533.

Merwin, H.E. \& Lombard, R.H. (1937). Econ. Geol., 32, 203.

Morimoto, N. \& Kullerud, G. (1963). Amer. Min., 48, 110.

Munson, R. A. (1966). Inorganic Chemistry, 5, 1296.

Roseboom, E. H. Jr. \& Kullerud, G. (1958). C. I. W. Yearbook, 57, 222.

Toulmin, P. 3rd. \& Barton, P. B. Jr. (1964). Geoch. Cosmoch. Acta, $28,641$. Yund, R. A. \& Kullerud, G. (1960). C.I.W. Yearbook, 54, 111. 
416 Fukuchilite, $\mathrm{Cu}_{8} \mathrm{FeS}_{8}$, A New Mineral from the Hanawa Mine Yund, R. A. \& Kullerud, G. (1963). Econ. Geol., 58, 1190. Yund, R. A. \& Kullerud, G. (1966). Jour. Petr., 7, 454.

Manuscript received 18 October 1968. 